\title{
Scholarship as Cultural Production in the Neoliberal University: Working Within and Against 'Deliverables'
}

\author{
MARY ELIZABETH LUKA \\ York University, Canada \\ ALISON HARVEY \\ University of Leicester, UK \\ MÉL HOGAN \\ Illinois Institute of Technology, USA
}

TAMARA SHEPHERD

University of Calgary, Canada

ANDREA ZEFFIRO

McMaster University, Canada

\begin{abstract}
This article focuses on the idea of scholarly work as cultural production to help understand how the tensions of precarious, early-career academic employment are articulated on a day-to-day basis in the context of pressures to efficiently produce monetizable 'deliverables.' Using a political economy of communication framework and an iterative methodological approach, the authors mobilize examples drawn from a collaborative set of activities they undertook as part of a broader research group of emerging Canadian scholars working in different international contexts between 2012 and 2015. The research conversation began in academic roundtables in 2013, and was furthered through a content analysis of articles collected from scholarly and general interest blog posts, newsletters, and magazines published online from July 2012 to April 2014. In this article, the authors explore emerging themes and document pressures to conform to neoliberal practices within the corporatized university, as well as suggest pathways for dissent and reinvention of academic labour.
\end{abstract}

KEYWORDS cultural production; neoliberal university; academic precarity; collaboration

Correspondence Address: Mary Elizabeth Luka, Sensorium Centre for Digital Arts \& Technology, School of Arts, Media, Performance \& Design, York University, Toronto, ON, M3J 1P3; Email:meluka@gmail.com 


\section{Introduction: Scholarship as Cultural Production}

Current attempts by universities to redefine their role in society - given late capitalist demands for tangible value to be derived from education - have prompted a renaissance of research practices expressed through an economic lens. Under these conditions, the concept of scholarship as cultural production is articulated through ideas about economically impactful deliverables, including a narrowly defined set of public engagement and outreach activities. In this context, 'deliverables' is a corporate management term used to denote tangible and quantifiable outcomes, valued for their capacity to be packaged and delivered to 'clients' (Shore, 2010). Examples include public talks and media appearances designed primarily to promote university products and personalities to the general public and funders who seek 'impact,' but who do not necessarily want to engage with the critical components of research. Within this promotional framework for economically-related deliverables, the most important indicators of success might include the size of audiences at such events, revenue streams generated by university research and development, and the ability to attract higherpaying students. In contrast, we understand scholarship as cultural production to more broadly include the role of public intellectuals, community activists, and other forms of participation in work, research, and creative endeavours both inside and outside the academic sphere.

This article reflects on two aspects of scholarship as cultural production, informed by (a) a purposive sampling (Yin, 2009, pp. 116-117) of online discussions about the neoliberal environment producing academic precarity, combined with (b) concerns arising from two roundtables at academic conferences in 2013 and 2014. We first consider the pressures academics face to efficiently produce monetizable 'deliverables,' and then analyze the rise in academic employment precarity as expressed in non-scholarly blog and professional articles written predominantly by academics.

This primary research was generated by seven researchers from 2012 to 2015, of which five participated in writing this article. ${ }^{1}$ Alison Harvey is a Lecturer in Media and Communication at the University of Leicester, and Tamara Shepherd is an Assistant Professor of Communication at the University of Calgary. Both draw on their experience of feminist participatory action research with local communities of game designers.

\footnotetext{
${ }^{1}$ The other two researchers on this project are Jacqueline Wallace, a Postdoctoral Fellow at Concordia University in Montreal who has significant experience in graphic design and social media start-ups, and Mélanie Millette, an Assistant Professor of Communication and Social Media at the Université de Québec à Montréal (UQAM) in Montreal and a former advertising professional. Our ongoing dialogues included roundtable discussions inviting input and sharing of others' experiences as well as our own. They were held at the Association of Internet Researchers in October 2013 with Hogan, Luka, Millette, and Wallace; and at the Canadian Communication Association in June 2014 with Harvey, Hogan, Luka, Millette, Shepherd, and Zeffiro.
} 
178 Mary Elizabeth Luka, Alison Harvey, Mél Hogan, Tamara Shepherd, Andrea Zeffiro

Additionally, Shepherd and Mary Elizabeth Luka make use of their critiques of broadcast policy development for this article. Luka is a Banting Postdoctoral Fellow at York University in Toronto, investigating creative citizenship at sites of collaborative interaction for which she mobilizes her extensive experience as a culture sector consultant and media director. Mél Hogan is an Assistant Professor of Communication at Illinois Institute of Technology (IIT) in Chicago and is interested in how scholarship relates to labour dynamics in research creation projects and collaborative productions between academics, designers, and other practitioners, including through her own entrepreneurial start-up. Andrea Zeffiro is an Assistant Professor of Communication Studies and Multimedia and the Academic Director for the Lewis and Ruth Sherman Centre for Digital Scholarship at McMaster University. Zeffiro draws on a decade of experience working in collaborative and interdisciplinary research networks and community-based social justice initiatives.

By 2012, all of us were emerging scholars interested in the exciting potential for crossovers between academic and non-academic spheres. Drawing on our experience as scholars and professionals, we wondered how economically-based deliverable imperatives would encroach on our potential scholarly research projects involving long-term, value-based partnerships with communication and creative professional associations, entrepreneurial start-ups and non-profits, media production and distribution organizations and activities, and video game production initiatives for women. These networks and research sites focus largely on equity, activism, and alternative approaches to mainstream or for-profit imperatives. The pressure for such partnerships to also beget financially-productive deliverables for the universities where we work exists alongside such value-based approaches. Our projects incorporate a wide range of online collaboration, co-creation, and experimentation activities including, for example, advocacy toolkits, frameworks for analyzing government data and policies, and collaboratively produced websites and promotional materials. These forms of scholarship as cultural production are desired by the 'corporatized university' insofar as they contribute to an institution's public profile. However, as Darin Barney's (2008) provocative analysis of participation and agency toward knowledge production suggests, knowledge cannot always be packaged as a publicity event, nor should it be. If academic workers are already mobilizing knowledge in their daily labours, whether it be mediated through research portfolios, channelled through pedagogical practices involving relevant groups of people, or reflected on and shared with colleagues and comrades in daily encounters, then why the push for publicity if not to demonstrate economic benefit?

Moreover, despite the ongoing potential of collaborative projects to broaden academic inquiry into new public and private spaces, many collaborations remain peripheral to traditional academic systems for recognition and advancement. Academic recognition still relies foremost on 
peer-assessed scholarly publications as well as on the ability to secure substantial research funding or otherwise contribute to university revenue streams. In other words, when conceived as outputs, some highly valued scholarly 'deliverables' paradoxically inhibit the collaborative processes and long-term commitments at sites of activist engagement in order to 'produce' scholarly research. This has significant implications for the corporatized university, an institution whose modern history reflects the transition from enlightenment idealism to corporate pragmatism, as we explore in detail below.

Concerns about the emphasis on economic deliverables are shared by academic unions and associations across Canada, as has been made evident by recent labour conflicts in higher education (e.g., Brown, 2015; CBC News, March 31, 2015). Participation in and analysis of the student-led Carré Rouge movement in Quebec indicate how systemic tensions involving economically-focused deliverables, in combination with precarious academic labour, provide the foundation for neoliberal academia. ${ }^{2}$ So do similar critiques emerging in the UK (Hall, Massey \& Rustin, 2013), Ireland, and other parts of Europe and North America (see Hanke \& Hearn, 2012). These critiques of the corporatized university circulated widely in academic literature, online forums, and informal conversations during the period from 2012 to 2015 when many of us were completing our doctoral studies and preparing to enter the academic workforce. We synthesize several such critiques below to set the stage for our subsequent discussion of the on-line articles we researched and the roundtables we developed.

\section{The Corporatized University: Deliverables in Relation to Labour Practices}

The late capitalist context provides ideal grounding for the creation of the corporatized university and its preoccupation with monetizable deliverables (Couldry \& McRobbie, 2010; Hall, Massey \& Rustin, 2013). Our analysis of the corporatized university is underpinned by the theoretical traditions of the political economy of communication (e.g., Garnham, 1995; McKercher \& Mosco, 2006; Melody, 2007), and the methodological approaches used in production studies (e.g., Gitlin, 1983; Mayer, 2011; Mayer, Banks \& Caldwell, 2009; Tuchman, 1978). Political economy offers an important critical lens through which to study labour practices as systems of economic production. In the context of our discussion here, these practices are mainly forms of labour emblematic of late capitalism marked by Western versions of

\footnotetext{
${ }^{2}$ In the spring of 2012, tens of thousands of Quebec post-secondary students went on strike to protest proposed tuition fee hikes, holding protests throughout the province, especially in Montreal. Faculty and staff supporters, unions, activist groups, and members of the public participated in the protests, with more than 250,000 people on the streets. For details, see $W i$ Journal of Mobile Media, 2012a \& 2012b.
} 
knowledge work, such as cultural and creative industries (Huws, 2003; Terranova, 2004). As Catherine McKercher and Vincent Mosco (2006, p. 493) note, for scholars like us who are interested in media (ownership and social construction), messages (content and discourse), and audiences (reception), the "labouring of communication" is of critical concern.

More specifically, the implications of a political economy of communication perspective can be made more explicit through a production studies approach, which helps us think through what it means to be engaged on the ground with labour practices that materially generate cultural products, economies, and identities. By thinking about the material working practices and conditions of contemporary scholars as a form of cultural production, we are able to attend to sites where negotiations of power, compensation, and productivity measures occur (see Mayer 2011, and Stevens 1998, for examples related to television production and architecture, respectively). In our case, academic newsletters, articles and blogs, coupled with conference roundtables, provided critical inroads. To observe academic precarity, we found it useful to illuminate the informal and formal hierarchies that structure scholarship as cultural production, as Pierre Bourdieu (1993) would suggest, by highlighting how scholars produce writing and analysis to negotiate those hierarchies.

Such analyses complement Bill Readings' (1996) influential account of the "university in ruins," which portrays an institution unsure of its role in contemporary social, economic, and cultural life. "The re-conception of the university as a corporation," he argues, results in a paradoxical relationship between higher learning and culture within a bureaucratic setting, "one of whose functions (products?) is the granting of degrees with a cultural cachet, but one whose overall nature is corporate rather than cultural" (Readings, 1996, p. 11; parenthetical insertion in original). So, although the university still "draws its legitimacy from culture" (Readings, 1996, p. 65), that legitimacy has to be re-cast within corporate management paradigms that demand, above all else, 'excellence', which translates into (primarily economic) deliverables. An intensification of the trends noted by Readings in the mid-1990s has been observed by several scholars commenting on changes in the university in relation to economic globalization and privatization (Aronowitz, 2000; Delanty, 2001; Mignolo, 2003; Tudiver, 1999), commodified learning (Archibald \& Feldman, 2010; Grineski, 2000), management culture (Burgan, 2006; Deem, Hillyard \& Reed, 2007; Giroux \& Myrsiades, 2001), and precarious academic employment (Jubas \& Kawalilak, 2012; Levin, Kater \& Wagoner, 2006; Rajagopal, 2002). For scholars working in this milieu, simply ignoring or denying the changes wrought by the corporatization of the university is no longer feasible. Simultaneously, it is crucial to be precise about what those changes mean for the status of academic values associated with teaching, learning, and scholarship (Steck, 2003) within institutional cultures of production that increasingly demand outputs beyond traditional scholarly publication. 
Reflecting on what has been characterized as the neoliberal political arrangement working to accelerate university corporatization (Ball, 2012; Rutherford, 2005), and to reshape other knowledge-work sectors (including, in our own direct experiences, public broadcasting, civil service, entrepreneurial start-ups, and non-profits), we agree with Jubas \& Kawalilak: (2012, p. 1):

Expectations that staff will 'do more with less,' forego salary increases that keep pace with inflation, secure outside funding for research, and adopt a hypercompetitive mindset, all while exposing themselves to new forms of surveillance to check compliance, are as present in the academy as they are in any other workplace.

One of the most vivid ways in which neoliberal logic has permeated academic work as cultural production has been through the introduction of indices seeking to measure 'impact' (UK), 'knowledge transfer' (US), and 'knowledge mobilization' (Canada) (see De Angelis \& Harvie, 2009; Horn, 2015; researchimpact.ca). This "audit culture" that informs the measurement of scholarly outputs "confuses 'accountability' with 'accountancy' so that 'being answerable to the public' is recast in terms of measures of productivity, 'economic efficiency' and delivering 'value for money"' (Shore, 2008, p. 281; see also Edu-factory Collective, 2011). In the process, Cris Shore (2008) argues, managerialism seeps into academic thinking and subjectivities, producing a "corrosive effect" (p. 292) that undermines autonomy and devalues the work of scholarship as cultural production, by reducing rich incarnations of knowledge to measurable deliverables.

This neoliberal and managerial approach to academic work stands in contrast to evidence of activism as cultural production. Although it has been plagued by "messy" (Law, 2004) political asymmetries and false dichotomies between academia and the non-academic milieu (Autonomous Geographies Collective, 2010), scholar activism as a component of scholarship as cultural production has long been a site for knowledge production responsive to social expression and struggle. Examples include jamming media signals, producing human rights videos, networking community radio efforts, and sharing tape recordings by hand (Branwyn, 1997; Miller \& Allor, 2009; Rodriguez \& El Gazi, 2007; Sreberny-Mohammadi \& Mohammadi, 1997). In the context of a corporatized university where non-traditional scholarly work has been subsumed under the logic of audit culture, something about the messiness of social engagement on the part of scholars eludes managerial techniques of measurement (Illner, 2011). Moreover, the possibilities for scholarly production to cut across disciplinary formations in the service of broader social justice and social transformation reflect the potential for academics to tap into a "mass intellectuality" that can open up "enormous scope for new alliances and forms of resistance" (Terranova \& Bousquet, 2004). The roundtables and content analysis we conducted between 2012 and 2014 
enabled us to examine how this process manifests in the lives of emerging scholars within and beyond the Canadian context.

\section{Understanding the Messiness of Scholarly Outputs: The Association of Internet Researchers (AoIR) Roundtable}

To understand scholarship as cultural production today - as both complicit with and resistant to neoliberal academia - our research group looked to other academics for guidance on how to navigate the field. This was no accident of timing; our research on this topic emerged from a genuine interest in realizing professional success in the academic job market, thinking critically about our labour practices and ongoing commitments to collaborative and partnershipbased work, including previous community and artistic relationships that are central to our research practices today.

In preparation for the 2013 annual conference of the Association of Internet Researchers (AoIR) in Denver, Colorado, Hogan, Luka, Millette, and Wallace collaboratively created a series of provocations for a roundtable chaired by labour theorist Vicki Mayer. The roundtable explored how the academic research milieu connects with specific entrepreneurial, social enterprise, and creative environments (e.g., public arts funding, public broadcasting, advertising, podcasting, graphic design, and website service companies). It drew on the participants' and audience members' work experiences in order to reflect on the challenges of valuing these experiences in the academic environment. Topics addressed included how creative labour, design-thinking, and activism fit together with academic methods and processes (e.g., in research-creation, commercialization partnerships, and action research, respectively). The panel analyzed the challenges and opportunities of what has come to be termed "research-creation," defined as the mobilization of creative practice in the production of original scholarly research (see e.g., Sawchuk \& Zeffiro, 2012). Such creative practices and their accompanying methods, including digital ethnography, self-critical observation, and digital media art production, were discussed as activities that could help or hinder legitimacy in the academy. Participants drew on their own experiences and challenges to exemplify these points. The recounting of non-academic work experiences by panelists from a feminist, critical labour point of view generated significant dialogue amongst attendees, who responded by noting the ways they too sought to integrate and combine their own academic, corporate, volunteer, and creative responsibilities.

During the roundtable discussion, concerns were raised regarding how difficult it is to cite, document, and represent collaborative fieldwork in the standard academic curriculum vitae and other scholarly forms. For example, the skilled teamwork often required to edit a documentary, co-create a toolkit for community activism, or build a website for a research project is not often reflected in the form of individually authored peer-reviewed journal articles, 
the gold-standard of research outputs. Thinking more critically about the possibilities for scholarship in the corporatized university, it seemed improbable that creative research-creation outputs or long-term collective research, based on values such as equity and access, could be reconciled with current academic publishing demands dependent on individual authorship. Indeed, the complexities inherent in collaborative work simultaneously resist the model of single-author scholarly publication and resituate the university as a participant in social struggles rather than as an ivory tower for distanced contemplation (Casas-Cortés \& Cobarrubias, 2007).

Another topic noted during the roundtable included inequities in pay for similar work in different arenas, such as graduate research assistant hourly rates and part-time teaching contracts versus corporate consulting rates to lead workshops, conduct research, organize strategic planning sessions, and manage creative production teams. Furthermore, some roundtable participants and audience members commented that they had been asked by supervisors or other academic authorities to narrow their expectations about the kind of academic career to expect, because they brought production skills drawn from digital media making, applied design, and project management experiences to the academic sphere. These individuals were not being encouraged to pursue research-based careers, but instead to return to corporate environments, or to become teachers in technical and professional programs. Such discouragement would seem to be changing given the emergence of academic collaborative processes in the field of digital humanities (Burdick, Drucker, Lunenfeld, Presner \& Schnapp, 2012), which aims to mobilize humanities research in ways that sometimes seem analogous to community-based activism or artist-led initiatives. But its similarity to the corporatized rapid-response nature of creative entrepreneurial business models and design-thinking often clash with more established forms of activism, creative production, and the individualized academic model of teaching and learning.

Current scholarly funding mechanisms, such as the Social Sciences and Humanities Research Council of Canada and the Research Councils in the United Kingdom, ratchet up these tensions through 'engagement' and 'impact' initiatives. These challenge scholars as producers of knowledge, artists, community members, and entrepreneurs to reach out to non-academic communities. Such initiatives are often explicitly connected to corporate agendas, prioritizing citizen involvement as 'client' engagements with commercializable research. Similarly, the requirement in UK funding applications to include 'impact' statements focuses on both social and economic benefits to non-academic users. This indicates the obligation to quantify outcomes from external research funding, which is crucial for career advancement in the academic environment. The key point here is that financial ('commercializability') and instrumental ('impact indicators') objectives restrict the capacity for researchers to resist the neoliberal status quo (O’Meara, 2014; Horn, 2015). For example, holding a feminist 
positionality in the academy often means producing additional justification for the value of research and community engagement, related to cooperative or jointly determined social goals, that may not result in measurable economic impacts (see e.g., Zeffiro \& Hogan, 2015). Such forms of legitimation include bridging social values with creative and workforceoriented life skills, such as shared knowledge, collaboration, self-expression, community involvement, and diverse cultural influences (see e.g., Branwyn, 1997; Miller \& Allor, 2009; Rodriguez \& El Gazi, 2007).

The AoIR roundtable provided us with examples of the challenges of scholarship as cultural production, including lack of recognition for collaborative work. It also indicated forms of resistance concerning wage equity and access to resources for non-economic goals. These articulations of resistance subsequently motivated our collection of newsletter, magazine, website, and blog articles on the topic of academic employment prospects for emerging scholars, which subsequently informed a second proposed roundtable at the Canadian Communication Association (CCA) annual conference in 2014.

\section{Narratives of Academic Precarity: Articles, Blog Posts and Media Coverage}

We purposively sampled 29 news items and commentaries from several sources by searching on a periodic basis for anything on the topic of academic employment for emerging scholars. Our sources included the two leading professional newsletters regarding the academy in the US and Canada (The Chronicle of Higher Education and University Affairs), two respected 'national' newspapers in the UK and the US that have a comprehensive online presence and regularly reference employment and related matters (The Guardian and The New York Times), and a range of other websites and individual blogs written by journalists and scholars over a seven-month period from November 2013 to June 2014 that explicitly referenced academic employment. ${ }^{3}$ Each sampled item included three to six links to other articles, reflecting various facets of recent or current situations in Canadian, American, and British universities. We analyzed the design of the items and the images used in each item's presentation, and conducted a discourse analysis of the headlines, assessing whether the content of the articles matched the headlines and visual images used to illustrate them. The trajectories and complaints we came across online amplified our concerns about the path to a tenure-track job. Headlines reflected a narrative of precarity and uncertainty. Several articles connected each writer's personal lack of tenure-track employment - or that of the individuals they had

\footnotetext{
${ }^{3}$ The full list of blogs and websites can be viewed here:

http://moreartculturemediaplease.com/scholarly/scholarship-as-cultural-production/
} 
interviewed - to the structural problems of the corporatized university. The headlines, which we collected as screengrabs, became a visual and discursive archive, which we built into a PowerPoint presentation for use at the CCA roundtable. ${ }^{4}$

This documentation of shared misery, frustration, or trauma provided overwhelming testimony about the emotional investments of precarious academic workers struggling to negotiate the linear academic career path associated with traditional scholarship, which many writers simultaneously romanticized and critiqued for being out of touch. Some typical insights are presented below, gleaned from analyzing the 29 items. We found that the majority of authors tried to make sense of whether personal or systemic failures (or both) were the crucial issues. The struggle to articulate the fraught nature of relatively limited opportunities within the highly stratified postsecondary system without whining or sounding entitled appeared in many of the blog posts, newsletters, and media/magazine articles. Indeed, it was a struggle for us to find evidence to the contrary: there was a dearth of optimism about the potential to find work in the field in the content we reviewed. We were discouraged by the volume of complaints, and so redoubled our efforts to identify affirmative experiences by rereading the publications we surveyed, and reflecting in greater depth about the experiences shared by audience members at the AoIR (and later, the CCA) roundtable(s), including by some of our supervisors, mentors and colleagues. Many of the latter came to tenured jobs and promotions in academia in different eras and although they struggled with other issues in their time, they were baffled by the anger and frustration expressed in the articles we tracked.

The predominance of the 'escape-from-scarcity' narrative within the collection of articles we surveyed demonstrates that numerous current and "ex-academics" are venting publicly as a means of resisting corporatization in the academy, and many are leaving the profession entirely. For example, in an article for Slate titled "Thesis Hatement," Rebecca Schuman (2013) laments: "I've finally gotten it through my thick head that I will not get a job - and if you go to graduate school, neither will you." Presented as a reality check of the paucity of tenure-track positions, the articles we surveyed focused on "recovered academics" who survived the "great disappointment" and moved on.

Many of the articles we reviewed feature images that are dark or apocalyptic, while their headlines describe academic labour through a distressing range of metaphors, from the Hunger Games (Odinshoot, 2014) and fast-food workers (Hoff, 2014), to warzones and drug gangs (Afonso, 2013; see Figure 1). Some highlighted the "big lie" about the availability of tenure-track positions (Benton, 2010). Although tenured and non-tenured

\footnotetext{
${ }^{4}$ The Powerpoint slides can be viewed here: http://moreartculturemediaplease.com/scholarly/scholarship-as-cultural-production/slideshow-ofimages/
} 
academics are framed as labourers, in some case they are also - however critically - described as "frauds," "imposters" (Barcan, 2014), and even "whores" (McMillan Cottom, 2013).

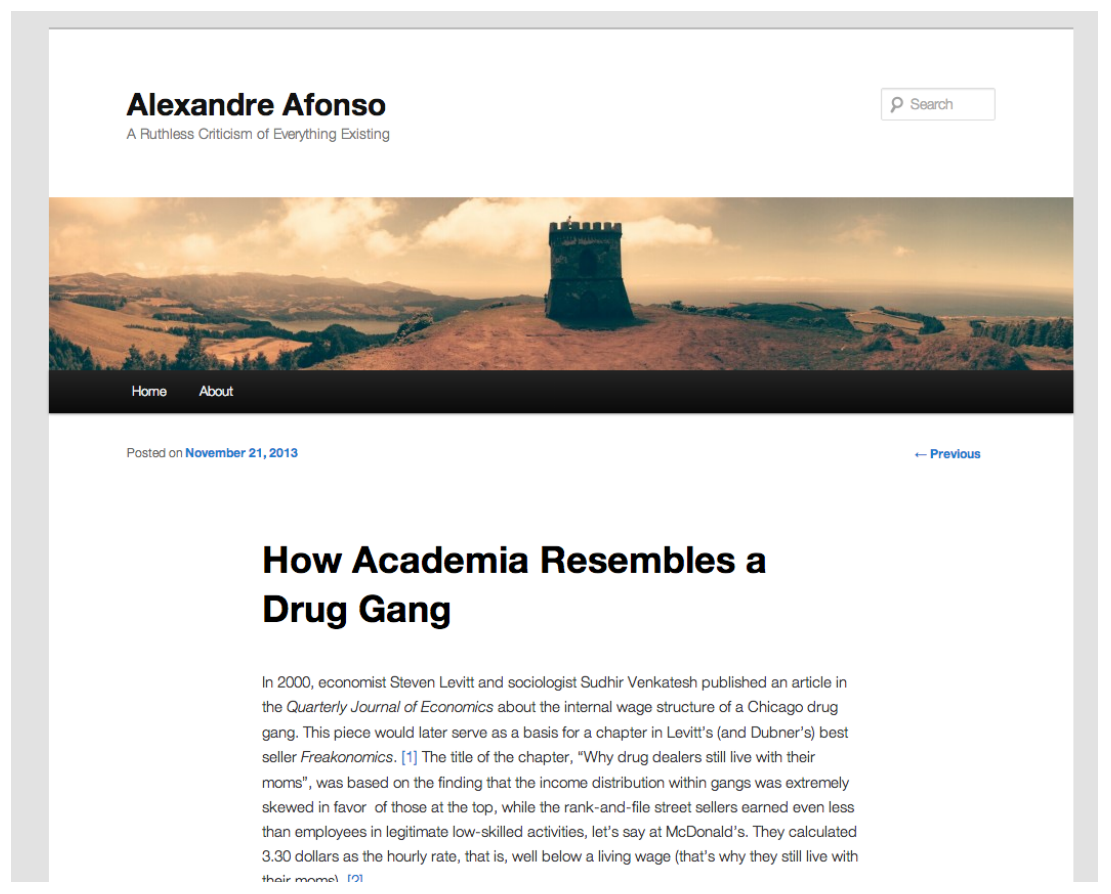

Figure 1. Screengrab of Alexandre Afonso's personal blog, November 21, 2013.

In many of the articles we examined, we also found numerous expressions of concern about the corporatized university as a site that, as discussed above, positions knowledge in the form of monetizable deliverables rather than intellectual engagement. For example, John Warner's (2014) account of Arizona State University's (ASU) plan to increase the teaching load for writing instructors from $4 / 4$ to $5 / 5$ without an increase in pay, paints a sombre scene. ASU is not the only higher education institution to take advantage of its contingent and casual work force. When Warner (2014) writes, "tenured faculty are largely in the business of producing graduates who become human shields, working for substandard wages in order to protect the $2 / 2$ teaching loads of their privileged tenured professors," his remarks may seem extreme. However, he is clearly asking each of us to challenge the academic "assembly line," and to be aware of our own contributions to manufacturing fraudulent futures (see e.g., Dalgleish \& Powell, 2014). 
The assembly line critique can be merged with critiques of the exploitative undertones of the "do what you love" mantra in both academic (Zeffiro \& Hogan, 2015) and cultural work (Hesmondhalgh \& Baker, 2008; Luka, 2014a, 2014b; McRobbie, 2003; Wallace, 2014). Authors of the articles we analyzed bemoaned terms such as 'assembly line' and 'do what you love' to describe the affective experience of precarity within a rigid academic hierarchy. In other words, doing what you love, or think is crucial for the advancement of society, is eclipsed by a multitude of written accounts of exploitation, diplomas attached to tremendous debt, and belated discovery of the preparation required to lead precarious academic lives.

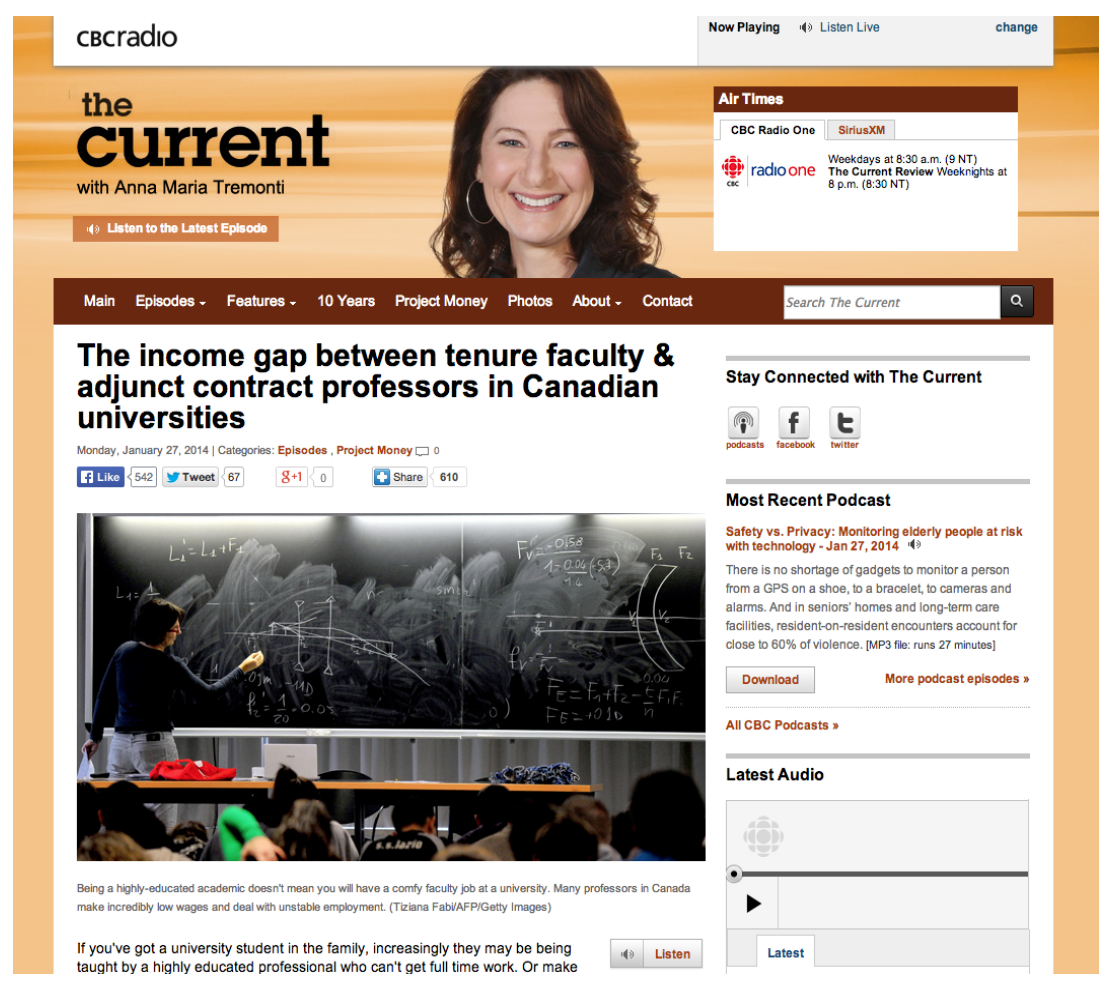

Figure 2. Screengrab of Anna Maria Tremonti's The Current (Canadian Broadcasting Corporation), January 27, 2014, (C) CBC Licensing.

For example, according to Shannon Higgens and Sarah Grant on an episode of CBC's The Current (2014; see Figure 2), the last decade alone has seen the number of $\mathrm{PhD}$ graduates in Canada double, meaning that twice as many qualified applicants vie for a limited number of jobs. Because new jobs are not being created at the same rate as doctorates are conferred (not that they ever were), the shift in employment opportunities means that most 
academics can hope to get their first tenure-track job in their mid-40s, which is ten years later than it was in the 1970s (Higgens \& Grant, 2014). It also means more competition in a time of diminishing resources, where fewer professorial posts in an environment of growing student numbers leads to increased class sizes and heavier administrative workloads for faculty in tandem with higher expectations around publication and grant acquisition (Higgens \& Grant, 2014). Recent countervailing enrolment trends nuance these pressures, especially in the humanities. When the number of highschool graduates decreases because of demographic shifts, humanities enrolment decreases more quickly, even while Canadian and international student enrolment at large urban universities increases (Brown, 2014). Moreover, in Canada, where tenured professors are among the best paid in the world, half the teaching work is done by part-time lecturers, a number that is only likely to increase under these conditions (Brown, 2012).

\section{Sarah Kendzior}

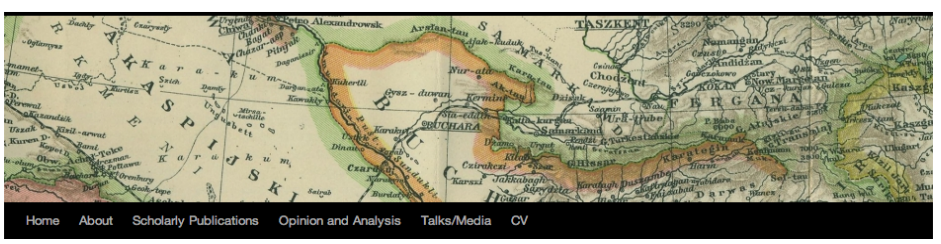

\section{$\leftarrow$ Self-Immolation and unemployment}

"Exploitation should not be a rite of passage" Posted on October 9. 2013

This is the English-language version of an interview I did with journalist Nigâr Hacizade of 5 Harfliler, a Turkish news site. My thanks to Nigâr for her terrific questions.

You were in academia and now you are "recovering from it". From outside, academia may seem like this wonderland, where you are given the opportunity to be engrossed in your work, your craft, and even if you are starter (ie aren't making much money), you get the respect and the nonmaterial satisfaction. How long did it take before you realized you weren going to do that? What was it like in that world and how hard was it to transition to freelance writing?

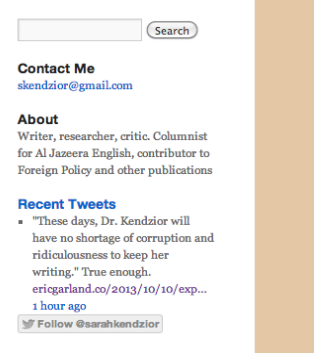

Figure 3. Screengrab of Sarah Kendzior's personal blog, October 8, 2013.

In addition to concerns about the growth of the employee pool and the incidence of part-time work, we also found class and gender issues discussed in the surveyed publications (Dunn, 2014; Faunce, 2010; Odinshoot, 2014). As just one example, Sarah Kendzior (2013; see Figure 3) notes that being "well-published, in top journals, with strong teaching evaluations and a solid reputation" in her field was not enough to secure a tenure-track job in the US. She identifies corollary class issues pertaining to funding and wealth. In the US, students with money "pay to play," as she puts it, while others accrue enormous debt and are more likely to drop out of graduate school, ensuring that they will never secure a tenure-track position. In addition, students from 
a lower socio-economic background often cannot afford to participate in unpaid internships or engage in the free labour that fills a vaguely required line on the CV that may - or may not - pay off later, either in the academy or in professional work (Sears \& Cairns, 2014). Furthermore, some of the authors we surveyed, including Miya Tokumitsu (2014) and Karen O'Donnell (2015), highlight the gendered dimension of such labour in their discussions of the still-common practice in the academic milieu of dismissing scholarly research driven by emotion and passion.

\section{One More Time With Feeling: The Canadian Communication Association (CCA) Roundtable and its Aftermath}

Drawing from our growing visual and textual archive, in May 2014, Harvey, Hogan, Luka, Millette, Shepherd, and Zeffiro assembled at the CCA annual conference to discuss the issues described above in a panel titled "Scholarship as Cultural Production in the Corporatized University." The conversation covered a range of topics. The neoliberal political context of the Canadian and UK university systems was articulated through discussion of the cultural clashes at play in research that aligns with increasing pressure from funding agencies and academic institutions to collaborate across academic, artistic, public, and corporate sectors. Potential strategies were discussed for gaining recognition (such as publication, funding, academic positions, and tenure) when engaging in non-traditional approaches, research design and outputs.

Throughout the discussion, the slideshow we created from our research sample played in the background. Provoked by these images, audience participation focused on the mental health of academics (see e.g., Academica Group, 2014) and the lessons we can learn as Canadian scholars from the managerial culture dominating the UK higher education landscape. A recent article by Rosalind Gill (2014) on the failure of academics to reflexively understand the structural conditions underpinning their own working environments and subjectivities, and the ways these conditions mirror those of cultural and creative workers, became the centerpiece of the conversation. Participants noted that even the most banal parts of academic work, such as the endless tide of emails and the impact of a mobile working mode (e.g., the ubiquity of portable computers, smart phones and requirements for rapid responses to 24-hour-a-day emails and texts) on individual well-being, can be linked to the transformation of the university over the last 30 years. Resembling workers in other creative fields marked by increasing neoliberal values and corporate management techniques (Garnham, 1995; Hesmondhalgh \& Baker, 2008; Huws, 2003), academics increasingly experience this always-on 'crunch time,' as well as pressure to engage in reputation management and self-promotion on personal social networks. Gill describes this shift, which is informed by increasing instrumentalization of 
research, as producing "a new form of 'academic capitalism"” (2014, p. 12). Consequently, although the work academics do is most certainly privileged, we must also address the underbelly of flexible and casualized labour upon which it is built, and the ways in which the increasingly affective dimensions of scholarly work (Gregg, 2011) can lead to "self-exploitation" (Gill, 2014).

The CCA roundtable discussion suggested that if we acknowledge the historical roots and structural characteristics of the neoliberal university, we can better understand our labour practices critically, and thus organize collective action in response. Participants also pointed out that in addition to the tremendous financial, social, and education capital required to gain entry into the academic realm, being able to provide deliverables requires further cultural capital to access the stakeholders acting as gatekeepers to governmental, community, institutional, and business worlds. One example we offered focused on how involving Canada's public broadcaster in a partnership project depends on the previous professional networks of the academics themselves. A broader example included the Carré Rouge movement in Quebec. The conversation in the room echoed an earlier publication documenting the movement, which described what was at stake as "a struggle over our values as a society and [our current] watershed moment that must be understood as part of a larger resistance to [...] budgets and policies that are decimating social services and public institutions" ( $\mathrm{Wi}$ Journal of Mobile Media, 2012b). In both cases, the question centres on how the contemporary university might address broader public values as well as its own internal needs for economic deliverables.

Moreover, discussion at both the AoIR and CCA roundtables, along with our analysis of the articles we reviewed, suggested that the most visible method the university employs to position itself in a demanding economic environment is by using promotional material that draws on tropes of knowledge expansion, enlightened thought, and critical thinking. These tropes obscure the part pervasive demands for deliverables plays in the devaluation of non-economic knowledge outcomes. This approach can be found in the majority of social sciences, arts and humanities $\mathrm{PhD}$ programs, where degrees are framed as upholding the virtues and liberties of an ideal university (Institute for the Public Life of Arts and Ideas, 2013). Yet, our examination shows that the pressure to produce scholarly research has a double-edged imperative: the commitments to deliverables serve to perpetuate the ongoing neoliberal corporatization of the university just as they offer potential means for resistance to it. Our concluding comments suggest a few such pathways for resistance.

\section{Moving Forward: Resituating Scholarship as Cultural Production}

In this article, we have critically reflected on the state of scholarship as cultural production, by analyzing public discussions about the rise in 
academic precarity, and examining the recent history of scholarly discourse and commentary emphasizing the financial and instrumental nature of academic deliverables. Identifying the problems tends to be less complicated, however, than generating concrete solutions. We cannot resolve the tensions we have outlined, but we can propose ways of moving forward as we reflect on our own situations within the corporatized university. We do this from the position of having occupied precarious 'emerging' academic roles - as doctoral students, postdoctoral fellows, contract and part-time instructors, and more recently for some, as tenure-track professors.

As part of a larger constellation of knowledge workers, scholars have a responsibility to question the conditions under which contributions are made to a broader 'knowledge economy.' As discussed above, visibility and selfpromotion naturally accompany a corporatized culture, requiring deliverables and impact to stand in for a broader conception of scholarship as cultural production. Indeed, knowledge mobilization, as it is often referred to under the auspices of neoliberalism (particularly in Canada), is focused on measuring output and strategizing visibility. In the process, knowledge becomes converted from a social relationship into a deliverable; from a means into an end in itself. The old adage 'publish or perish' might thus be updated to 'public and publish, or perish.'

Tracing the decades-long resonances of economic privatization, Garry Potter (2015) describes the neoliberal university in Canada and its management strategies, especially the casualization of its teaching labour force, as the "Walmartization" of higher education, a process also at play in the American, UK, and Irish higher education sectors. The traditional unions and faculty associations that operate in Canada play an important role in resisting such ongoing instrumentalization of the workforce. Yet, the voluntary unionization of higher education in the UK has little to no organizing power against changing workplace norms such as those ushered in by the Research Excellence Framework (the UK's national, standardized system for assessing scholarship across institutions; see http://www.ref.ac.uk/). More informally, conversations about the historical segregation of full-time stable labour from precarious adjunct and contract work in unionized and non-unionized environments alike erupted over the CCA's mailing list during the summer of 2014. Reflecting on what tenured professors could do to address academic precarity in their own institutions resulted in tangible commitments during the labour conflicts of 2015 at York University and the University of Toronto, to make videos, walk the picket lines and otherwise articulate support for part-time and contract academics.

In our research group, organizing for more inclusive and equitable working conditions is at the core of our training as feminist scholars, activists, artists, entrepreneurs and policy makers. Our positioning entails investment in scholarship and research within the university, and in cultural and political initiatives and programs outside of it, including attempts to secure stable employment, tenure, promotion, and to maintain one's research profile. It is 
in straddling these spaces that academics may come to see the university as a site of cultural production that continues to be contested and can be reshaped.

According to the articles we surveyed, for a contingent labour force, energies are often expended in amassing short-term teaching contracts to meet a living wage, fulfilling those contracts and anticipating future options. The roundtables we conducted highlighted how, outside of teaching commitments and funded peer-reviewed publications, one is expected to continue with unpaid scholarly output should one hope to maintain a competitive edge in the academic job market (e.g., community engagement, activist work, the production of unfunded research for peer-reviewed publications and conferences, and the establishment of a public persona during unpaid periods of time). In coming to terms with the state of the corporatized university, however, we also recognize the significance of engaging in what we were trained to do. Alternate routes can be carved out within and around the university to rethink where and how energies (i.e., labour) are invested. Our research suggests that by engaging in a sustained interrogation of the conditions under which we are expected to do academic labour across the corporatized university, we are also involved in critical knowledge production as individuals and as a cohort, in official and unofficial spaces.

Of course, simply thinking about it is not enough, no matter how many are collectively involved in that thinking. We need more of the critical considerations analyzed in this article to find their way into administrative leadership perspectives, including those of university boards of governors, presidents, deans and faculty chairs. We also need to continue to mobilize dialogue into strategic action through involvements in protests, academic governance, collaborative and creative work, and mentorship, regardless of whether these activities are paid. It is also necessary to continue to have public dialogues - including at conferences and within collaborative pieces such as this - so that we may iteratively re-engage with long-standing and emerging issues, especially as we navigate individual trajectories within, alongside, and outside of academia. This too takes time, and one's ability to speak candidly and engage in public action is supported by a certain level of professional stability and sustenance. For these reasons, we find strength in collaboration. It is from within such formal and informal collectivities that we see directions for transitioning private conversations and individual experiences into public dialogue, research and action.

\section{Acknowledgements}

Luka thanks the Canadian Social Sciences and Humanities Research Council for funding support through the Vanier Scholarship and Banting Fellowship during the research and writing of this article. The authors thank the article writers referenced, roundtable attendees and others for their frank 
assessments, and for permission to use the materials featured, as well as the reviewers and editors of the article, whose contributions made it stronger.

\section{References}

Academica Group. (2014, January 30). More awareness, stats needed on mental health among $\mathrm{PhD}$ students. Retrieved from http://academica.ca/top-ten/more-awareness-stats-neededmental-health-among-phd-students

Afonso, A. (2013, November 21). How academia resembles a drug gang. Retrieved from https:/alexandreafonso.wordpress.com/2013/11/21/how-academia-resembles-a-drug-gang/

Archibald, R.B., \& Feldman, D.H. (2010). Why does college cost so much? Oxford: Oxford University Press.

Aronowitz, S. (2000). The knowledge factory: Dismantling the corporate university and creating true higher learning. New York: Beacon.

Autonomous Geographies Collective (2010). Beyond scholar activism: Making strategic interventions inside and outside the neoliberal university. ACME: An International EJournal for Critical Geographies, 9, 245-274.

Ball, R. (2012). Global education Inc.: New policy networks and the neo-liberal imaginary. London: Routledge.

Barcan, R. (2014, January 9). Why do some academics feel like frauds? Timeshighereducation.co.uk. Retrieved from http://www.timeshighereducation.co.uk/features/why-do-some-academics-feel-likefrauds/2/2010238.article

Barney, D. (2008). Politics and emerging media: The revenge of publicity. Global Media Journal (Canadian Edition), 1(1), 89-106.

Benton, T. H. (2010, February 8). The big lie about the life of the mind. Chronicle of Higher Education. Retrieved from http://chronicle.com/article/The-Big-Lie-About-the-Lifeof/63937/

Bourdieu, P. (1993). The field of cultural production: Essays on art and literature. New York: Columbia University Press.

Branwyn, G. (1997). Jamming the media. New York: Chronicle Books.

Brown, L. (2012, March 22). Why Canada's professors are the best (best-paid, that is). The Toronto Star. Retrieved from http://www.thestar.com/news/canada/2012/03/22/why_canadas_professors_are_the_best_b estpaid_that_is.html

Brown, L. (2014, September 22). Ontario university enrolment down for the first time in 15 years. Retrieved from http://www.thestar.com/yourtoronto/education/2014/09/22/ontario_university_enrolment_d own_for_first_time_in_15_years.html

Brown, L. $(2015, \overline{M a r c h} \overline{2} 6)$. U of T strike over as teaching assistants vote to enter arbitration. The Toronto Star. Retrieved from http://www.thestar.com/yourtoronto/education/2015/03/26/u-of-t-strike-over-as-teachingassistants-vote-to-enter-arbitration.html

Burdick, A., Drucker, J., Lunenfeld, P., Presner, T., \& Schnapp, J. 2012. Digital humanities. Cambridge, MA: MIT. Retrieved from https://mitpress.mit.edu/sites/default/files/titles/content/9780262018470_Open_Access_Edi tion.pdf

Burgan, M. (2006). What ever happened to the faculty?: Drift and decision in higher education. Baltimore: Johns Hopkins University Press. 
194 Mary Elizabeth Luka, Alison Harvey, Mél Hogan, Tamara Shepherd, Andrea Zeffiro

CBC News. (2015, March 31). York University strike ends as CUPE 3903 votes yes to new contract. Retrieved from http://www.cbc.ca/news/canada/toronto/york-university-strikeends-as-cupe-3903-votes-yes-to-new-contract-1.3017060

Casas-Cortés, M., \& Cobarrubias, S. (2007). A la deriva por los circuitos de la máquina cognitiva. Circuitos feministas, mapas en red e insurrecciones en la universidad. Brumaria 7. Retrieved from http://www.countercartographies.org/download/a_la_deriva_por_los_circuitos_de_la_maqu ina_cognitiva__brumaria_7.pdf

Couldry, N., \& McRobbie, A. (2010). The death of the university, English style. Culture Machine Interzone, November 2010, 1-3. Retrieved from culturemachine.net/index.php/cm/article/viewFile/417/430

Dalgleish, M., \& Powell, D. (Eds.) (2014). Graduate training in the 21st century. Mediacommons. http://mediacommons.futureofthebook.org/alt-ac/cluster/graduate-training21 st-century

De Angelis, M., \& Harvie, D. (2009). 'Cognitive capitalism' and the rat-race: How capital measures immaterial labour in British universities. Historical Materialism, 17(3), 3-30.

Delanty, G. (2001). Challenging knowledge: The university in the knowledge society. Buckingham: Open University Press.

Deem, R., Hillyard, S., \& Reed, M. (2007). Knowledge, higher education, and the new managerialism: The changing management of UK universities. Oxford: Oxford University Press.

Dunn, S. (2014, January 5). Digital humanists: If you want tenure, do double the work. Vitae. Retrieved from https://chroniclevitae.com/news/249-digital-humanists-if-you-want-tenuredo-double-the-work\#sthash.Ztga1b4V.dpuf

EduFactory Collective. (2011). University struggles and the system of measure. EduFactory Web Journal, 1, 3-5. Retrieved from http://www.edu-factory.org/wp/wpcontent/uploads/2011/09/first issue1.pdf

Faunce, R. (2010, September 2). An underclass is educating your children. The Chronicle of Higher Education. Retrieved from https://chronicle.com/article/An-Underclass-IsEducating/124201/

Garnham, N. (1995). Political economy and cultural studies: Reconciliation or divorce? Critical Studies in Mass Communication, 12(1), 62-71.

Gill, R. (2014). Academics, cultural workers and critical labour studies. Journal of Cultural Economy 7(1), 12-30.

Giroux, H.A., \& Myrsiades, K. (Eds.) (2001). Beyond the corporate university: Culture and pedagogy in the new millennium. Lanham, MD: Rowman \& Littlefield.

Gitlin, T. (1983/2000). Inside prime time. Berkeley: University of California Press.

Gregg, M. (2011). Work's intimacy. Cambridge: Polity Press.

Grineski, S. (2000). "I've a feeling we're not in Kansas anymore": The commercialization and commodification of teaching and learning in higher education. Bulletin of Science, Technology \& Society, 20(1), 19-28.

Hall, S., Massey, D., \& Rustin, M. (2013). After neoliberalism: Analysing the present. Soundings, 53, 8-22.

Hanke, B., \& Hearn, A. (2012). Out of the ruins, the university to come. Topia 28, 11-20. Retrieved from http://topia.journals.yorku.ca/index.php/topia/issue/view/2085/showToc

Hesmondhalgh, D., \& Baker, S. (2008). Creative work and emotional labour in the television industry. Theory, Culture \& Society, 25(7-8), 97-118.

Higgens, S., \& Grant, S. (2014, January 27). The income gap between tenure faculty \& adjunct contract professors in Canadian universities. CBC's The Current. Retrieved from http://www.cbc.ca/radio/thecurrent/jan-27-2014-1.2908720/the-income-gap-betweentenure-faculty-adjunct-contract-professors-in-canadian-universities-1.2908723

Hoff, J. (2014, January 24). Are adjuncts the fast-food workers of the academic world? The Guardian. Retrieved from http://www.theguardian.com/commentisfree/2014/jan/24/exploitation-of-adjunctprofessors-devalues-higher-education

Studies in Social Justice, Volume 9, Issue 2, 176-196, 2015 
Horn, D. (2015, January 20). Impact factors. Inside Higher Ed. Retrieved from https://www.insidehighered.com/blogs/university-venus/impact-factors

Huws, U. (2003). The making of a cybertariat: Virtual work in a real world. New York: Monthly Review Press.

Illner, P. (2011). Against audited education: The emergence of an activist pedagogy. EduFactory Web Journal, 1, 68-81. Retrieved from http://eipcp.net/n/1317065729

Institute for the Public Life of Arts and Ideas. (2013). White paper on the future of the PhD in the Humanities. Montreal: McGill University. Retrieved from http://www.mcgill.ca/iplai/files/iplai/white_paper_on_the_future_of_the_phd_in_the_huma nities_dec_2013_1.pdf

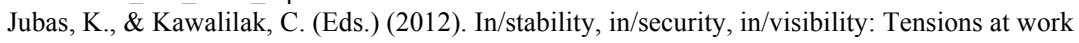 for tenured \& tenure stream faculty in the neoliberal academy. Workplace: Journal of Academic Labor, 21, 1-2. Retrieved from http://ices.library.ubc.ca/index.php/workplace/article/view/183750

Kendzior, S. (2013, October 9). Exploitation should not be a rite of passage. Retrieved from http://sarahkendzior.com/2013/10/09/exploitation-should-not-be-a-rite-of-passage/

Law, J. (2004). After method: Mess in social science research. New York: Routledge.

Levin, J.S., Kater, S.T., \& Wagoner, R.L. (2006). Community college faculty: At work in the new economy. New York: Palgrave Macmillan.

Luka, M.E. (2014a). The promise of crowdfunding in documentary filmmaking and audience development. In R. DeFillipi \& P. Wikstrom (Eds.), International perspectives on business innovation and disruption in the creative industries: Film, video, photography (pp.149176). Northampton, MA: Edward Elgar Publishing Ltd.

Luka, M.E. (2014b) Towards creative citizenship: Collaborative cultural production at CBC ArtSpots (Unpublished doctoral dissertation). Concordia University, Montreal.

Mayer, V. (2011). Below the line: Producers and production studies in the new television economy. Durham, NC: Duke University Press.

Mayer, V., Banks, M.J., \& Caldwell, J.T. (Eds.) (2010). Production studies: Cultural studies of media industries. New York: Routledge.

McKercher, C., \& Mosco, V. (2006). Editorial: The labouring of communication. Canadian Journal of Communication, 31(2), 493-497. Retrieved from http://www.cjconline.ca/index.php/journal/article/view/1841/1942

McMillan Cottom, T. (2013, October 13). Academic whores. Retrieved from http://tressiemc.com/2013/10/13/academic-whores/

McRobbie, A. (2003). British fashion design: Rag trade or image industry? London: Routledge.

Melody, W.H. (2007). Markets and policies in new knowledge economies. In R. Mansell, C. Avgerou, D. Quah \& R. Silverstone (Eds.), The Oxford handbook of information and communication technologies (pp. 55-74). Oxford: Oxford University Press.

Mignolo, W. (2003). Globalization and the geopolitics of knowledge: The role of the humanities in the corporate university. Nepantla: Views from South, 4(1), 97-119.

Miller, L., \& Allor, M. (2009). Strategies for representing the pain of others: The video advocacy institute. Canadian Journal of Communication, 34(1), 137-141.

O’Donnell, K. (2015, July 23). Why academia needs emotional, passionate women. The Guardian. Retrieved from http://www.theguardian.com/women-inleadership/2015/jul/23/why-academia-needs-emotional-passionate-women

O’Meara, K. (2014, January 13). Change the tenure system. Inside Higher Ed. Retrieved from http://www.insidehighered.com/advice/2014/01/13/essay-calls-reform-tenure-andpromotion-system

Odinshoot, A. (2014, January 20). The odds are never in your favor: Why the academic job market is like the Hunger Games. The Chronicle of Higher Education. Retrieved from https://chronicle.com/article/The-Odds-Are-Never-in-Your/144079/

Potter, G. (2015). Rebellious responses to the Walmartization of Canadian higher education. Alternate Routes: A Journal of Critical Social Research, 26, 125-144. Retrieved from http://www.alternateroutes.ca/index.php/ar/article/view/22315

Rajagopal, I. (2002). Hidden academics: Contract faculty in Canadian universities. Toronto: University of Toronto Press. 
196 Mary Elizabeth Luka, Alison Harvey, Mél Hogan, Tamara Shepherd, Andrea Zeffiro

Readings, B. (1996). The university in ruins. Cambridge, MA: Harvard University Press.

ResearchImpact.ca (RIR): Turning Research Into Action. (n.d.). Retrieved from http://researchimpact.ca/

Rodriguez, C., \& El Gazi, J. (2007). The poetics of indigenous radio in Colombia. Media Culture and Society 29(3), 449-468.

Rutherford, J. (2005). Cultural studies in the corporate university. Cultural Studies, 19(3), 297317.

Sawchuk, K., \& Zeffiro, A. (2012). Media arts revisited (MARs). Canadian Journal of Communication, 37(1), 3-4.

Schuman, R. (2013). Thesis hatement: Get a literature Ph.D. will turn you into an emotional trainwreck, not a professor. Slate. Retrieved from http://www.slate.com/articles/life/culturebox/2013/04/there_are_no_academic_jobs_and_g etting_a_ph_d_will_make_you_into_a_horrible.html

Sears, A., \& Cairns, J. (2014, January 24). Austerity U: Preparing students for precarious lives. New Socialist Webzine. Retrieved from http://www.newsocialist.org/736-austerity-upreparing-students-for-precarious-lives

Shore, C. (2008). Audit culture and Illiberal governance: Universities and the politics of accountability. Anthropological Theory 8(3), 278-298.

Shore, C. (2010). Beyond the multiversity: Neoliberalism and the rise of the schizophrenic university. Social Anthropology, 18(1), 15-29.

Sreberny-Mohammadi, A., \& Mohammadi, A. (1997). Small media and revolutionary change. In A. Sreberny-Mohammadi, D. Winseck, J. McKenna \& O. Boyd-Barrett (Eds.), Media in global context (pp. 220-235). New York: Arnold.

Steck, H. (2003). Corporatization of the university: Seeking conceptual clarity. The Annals of the American Academy of Political and Social Science, 585(1), 66-83.

Stevens, Garry. (1998). The favored circle: The social foundations of architectural distinction. Cambridge, MA: The MIT Press.

Terranova, T. (2004). Network culture: Politics for the information age. London: Pluto Press.

Terranova, T., \& Bousquet, M. (2004). Recomposing the university. Mute Magazine. Retrieved from http://www.metamute.org/editorial/articles/recomposing-university

Tokumitsu, M. (2014). In the name of love. Jacobin. Retrieved from https://www.jacobinmag.com/2014/01/in-the-name-of-love/

Tuchman, G. (1978). Making news: A study in the construction of reality. New York: Free Press.

Tudiver, N. (1999). Universities for sale: Resisting corporate control over Canadian higher education. Toronto: James Lorimer.

Wallace, J. (2014). Handmade 2.0: Women, DIY networks and the cultural economy of craft (Unpublished doctoral dissertation). Concordia University, Montreal.

Warner, J. (2014, December 16). ASU and the non-tenured human shields. Inside Higher Ed. Retrieved from https://www.insidehighered.com/blogs/just-visiting/asu-and-non-tenuredhuman-shields

Wi Journal of Mobile Media. (2012a). Out of the mouth of casseroles I. Retrieved from http://wi.mobilities.ca/category/2012-6-2-out-of-the-mouth-of-casseroles-i/

Wi Journal of Mobile Media. (2012b). Out of the mouth of casseroles II. Retrieved from http://wi.mobilities.ca/category/2012-6-2-out-of-the-mouth-of-casseroles-ii/

Yin, R.K. (2009). Case study research: Design and methods. $4^{\text {th }}$ Revised Edition. Thousand Oaks, CA: Sage.

Zeffiro, A., \& Hogan, M. (2015). Suture and scars: Evidencing the struggles of academic feminism. In K. Silva \& K. Mendes (Eds.), Feminist erasures: Challenging backlash culture (pp. 36-53). New York: Palgrave Macmillan.

Studies in Social Justice, Volume 9, Issue 2, 176-196, 2015 